Original Article

\title{
Study Travel Time in the Movement of Passengers and Baggage at the Arrival Station of Sultan Hasanuddin International Airport Makassar
}

\author{
F Sabur ${ }^{1, *}$ \\ 1 Civil Aviation Safety and Engineering Academy, Salodong, Makassar - South Sulawesi, Indonesia \\ * Correspondence: fatmawati.sabur.fs@gmail.com
}

Received: 18 June 2020; Accepted: 12 October 2020; Published: 20 December 2020

\begin{abstract}
Airport provides facilities for services to aircraft, passengers, and goods. One of the activities at the airport is handling your luggage. At some particular time, especially in crowded flight, a passenger still faces delays in receiving baggage at the arrival terminal. The purpose of the research is to know the travel time difference and the factors that influence the travel time differences in the movement of passengers and baggage at the arrival terminal of Sultan Hasanuddin International Airport of Makassar. The type of research is a correlation study, using primary data in the form of data direct field measurements as well as secondary data from the monthly reports-MATSC Support Operations Division Aeronautical Information Service in the form of fixed flight schedules and Side Air Operations Division in the form of data movement apron. Processing the data is by using SPSS version 18:00 The findings is: the smallest time difference between the passenger and baggage occurs when using the bus, followed a garbarata and the greatest difference in time when walking, so that it can be concluded that the use of buses more effective in reducing delays in receiving the baggage at the arrival terminal of International Airport Sultan Hasanuddin of Makassar.
\end{abstract}

Keywords: passenger travel time, travel time baggage, ground handling services

\section{Introduction}

Selecting the transportation modes can be adjusted based on the needs and conditions which available in the field. Air transportation is the fastest transportation with a wide reach [1,2]. In the operation of the airport, there are various interactions among the main components, namely: airport, airline operator, and service user. The airport provides facilities for service to aircraft, passengers, and goods [3]. The baggage service is part of Ground Handling service of the aircraft, starting in the parking position at the apron in a stop engine and block-on position. The performance of the airport service is one of the points that must be considered [4-5]. The Delayed that the passengers faced in receiving their luggage at arrival terminal is because of the travel time difference between the time of the passenger from the plane to the arrival terminal and the luggage from the plane to the baggage room in the arrival terminal [6]. To answer the existing problems, where the purpose of this study can be formulated as follows: to find out the difference of travel time of passengers and baggage movement, and factors that affecting the difference at the arrival terminal of Sultan Hasanuddin International Airport of Makassar [7-8]. 


\section{Methodology of the Research}

The research is conducted at Sultan Hasanuddin International Airport of Makassar, 2017. Type of research is correlation research; it aims to test the relationship among variables by using quantitative data approach. The data is collected by observing and measuring the travel time of passengers' movement and passengers' baggage from moving off from the plane to the arrival terminal, while the secondary data is written materials from data source which is consist of monthly recap report operations in the Aeronautical Information Service's Support-MATSC Division of Fixed Aircraft Operations and the Apron Movement Control (AMC) Division in the form of apron motion data. The technique of data analysis is regression and comparison analysis by using SPSS, processing regression statistical analysis, and one-way Anova [9-11].

The comparison of Moda access:

1. Variables of the research

The variables of the research are: X1 (number of Ground Service personnel), X2 (Number of Ground Service equipment), X3 (the distance of the passenger's movement to Arrival terminal), $\mathrm{X} 4$ (the distance of baggage movement to Arrival terminal), dan $\mathrm{Y}$ (travel time different of the passengers and baggage movement)

2. Result of Garbarata analysis (Avio) [12].

Table 1. The Anova analysis of a garbarata with dependent variable of time

\begin{tabular}{llccccc}
\multicolumn{7}{c}{ ANOVA $^{\mathbf{b}}$} \\
\hline & Model & Sum of Squares & df & Mean Square & F & Sig. \\
\hline 1 & Regression & 861.982 & 4 & 215.496 & 25.448 & $.000^{\text {a }}$ \\
Residual & 7375.703 & 871 & 8.468 & & \\
& Total & 8237.685 & 875 & & & \\
\hline
\end{tabular}

a. Predictors: (Constant), distance of baggage, number of ground service personnel, number of equipent, distance of the pasanger)

b. Dependent Variable: time

Based on the table 1 above, the significant value of 0,000 with a $95 \%$ belief level or $\alpha=0.05$, this means that the position of the test point of significance and F-count on the normal distribution curve resides in the Ho rejection $[13,14]$. It shows that the four independent variables $(X 1, X 2, X 3, X 4)$ have a significant influence on the variable $Y$ [15]. Thus, Ho stating that no influence $X 1, X 2, X 3, X 4$ to $Y$ is rejected as presented on Table 2 .

Table 2. RegressionCoefficients garbarata analysis with time as dependent variable

\begin{tabular}{|c|c|c|c|c|c|c|c|c|}
\hline \multirow{2}{*}{\multicolumn{2}{|c|}{ Model }} & \multicolumn{2}{|c|}{$\begin{array}{l}\text { Unstandardized } \\
\text { Coefficients }\end{array}$} & \multirow{2}{*}{$\begin{array}{c}\text { Standardized } \\
\text { Coefficients } \\
\text { Beta }\end{array}$} & \multirow[t]{2}{*}{$\mathrm{T}$} & \multirow[t]{2}{*}{ Sig. } & \multicolumn{2}{|c|}{$\begin{array}{c}\text { Collinearity } \\
\text { Statistics }\end{array}$} \\
\hline & & $\mathrm{B}$ & Std. Error & & & & Tolerance & VIF \\
\hline \multirow[t]{5}{*}{1} & (Constant) & 6.820 & 2.668 & & 2.556 & .011 & & \\
\hline & Personnel & -.968 & .486 & -.068 & -1.991 & .047 & .875 & 1.143 \\
\hline & Tools & -.376 & .516 & -.025 & -.730 & .466 & .876 & 1.142 \\
\hline & $\begin{array}{l}\text { Passenger's } \\
\text { distance }\end{array}$ & -.005 & .001 & -.135 & -3.719 & .000 & .777 & 1.287 \\
\hline & $\begin{array}{l}\text { Baggage's } \\
\text { distance }\end{array}$ & .015 & .002 & .325 & 9.900 & .000 & .952 & 1.050 \\
\hline
\end{tabular}

a. Dependent Variable: time 
It can be shown as follows:

$$
\begin{gathered}
\mathrm{Y}=\alpha+\beta \_1 \mathrm{X} \_1+\beta \_2 \mathrm{X} \_2+\cdots+\beta \_4 \mathrm{X} \_4+\varepsilon \\
\mathrm{Y}=6,820-0,968 \mathrm{X} \_1-0,376 \mathrm{X} \_2-0,005 \mathrm{X} \_3+0,015 \mathrm{X} \_4
\end{gathered}
$$

It can be shown that (X1) affect the Passenger and Baggage time difference $(\mathrm{Y})$. With the regression coefficient $\beta_{-} 1$ (X1) is negative, indicating the influence of variable $X 1$ inversely with $Y$, the variable $X 2$ has no effect on $Y$, the variable $X 3$ affect $Y$. With negative regression coefficient $\beta \_3$ $(\mathrm{X} 3)$, this indicates that the effect of $\mathrm{X} 3$ is proportional reversed by $\mathrm{Y}$, the $\mathrm{X} 4$ has an effect on $\mathrm{Y}$. The regression coefficient $\beta_{-} 4(\mathrm{X} 4)$ is positive [16-17]. This shows that the influence of $X 4$ is unidirectional with $Y$. So that not all independent variable $(X)$ has significant effect. Variable $X 2$ has no significant effect on $\mathrm{Y}$, then the new model is produced, as follows:

$$
\text { Y=6,820-0,968X_1-0,005X_3+0,015X_4 }
$$

\section{Results}

The result of a bus analysis is presented on Table 3 .

Table 3. Anova bus with time as dependent variable

\begin{tabular}{llllcrrr}
\hline \multirow{2}{*}{ Model } & Sum of Squares & Df & $\begin{array}{c}\text { Mean } \\
\text { Square }\end{array}$ & F & Sig. \\
\hline \multirow{2}{*}{1} & Regression & 1394.430 & 4 & 348.607 & 72.945 & $.000^{\mathrm{a}}$ \\
& Residual & 4162.569 & 871 & 4.779 & & \\
& Total & 5556.999 & 875 & & & \\
\hline
\end{tabular}

a. Predictors: constanta, distance of baggage, number of ground service personnel, number of equipent, distance of the pasanger). Dependent Variable: time

Based on the Table 3 above, a significant value of 0,000 at a $95 \%$ beliefe level or $\alpha=0.05$, this means that the position of the test results of significance and F-count on the normal distribution curve is in the rejection of Ho, it means that the four independent variables $\left(X_{1}, X_{2}, X_{3}, X_{4}\right)$ have a significant effect on the variable $\mathrm{Y}$ as on Table 4 . Thus Ho stating that no influence $\mathrm{X} 1, \mathrm{X} 2, \mathrm{X} 3, \mathrm{X} 4$ to $\mathrm{Y}$

\begin{tabular}{|c|c|c|c|c|c|c|c|c|}
\hline & \multirow[t]{2}{*}{ Model } & \multicolumn{2}{|c|}{$\begin{array}{c}\text { Unstandardized } \\
\text { Coefficients }\end{array}$} & \multirow{2}{*}{$\begin{array}{c}\text { Standardized } \\
\text { Coefficients } \\
\text { Beta }\end{array}$} & \multirow[t]{2}{*}{$\mathrm{t}$} & \multirow[t]{2}{*}{ Sig. } & \multicolumn{2}{|c|}{$\begin{array}{c}\text { Collinearity } \\
\text { Statistics }\end{array}$} \\
\hline & & B & Std. Error & & & & Tolerance & VIF \\
\hline \multirow[t]{5}{*}{1} & (Constanta) & 6.024 & 1.300 & & 4.633 & .000 & & \\
\hline & Personnel & -1.444 & .239 & -.193 & -6.049 & .000 & .842 & 1.187 \\
\hline & Tools & .328 & .285 & .036 & 1.151 & .250 & .902 & 1.109 \\
\hline & $\begin{array}{l}\text { Passanger's } \\
\text { distance }\end{array}$ & -.010 & .001 & -.708 & $\begin{array}{c}-12.72 \\
9\end{array}$ & .000 & .278 & 3.600 \\
\hline & $\begin{array}{l}\text { Bagage's } \\
\text { distances }\end{array}$ & .014 & .001 & .838 & 14.920 & .000 & .272 & 3.670 \\
\hline
\end{tabular}
is rejected [18-20].

Table 4. Result of Regression Coefficients bus analysis with time as dependent variable

a. Dependent Variable: Time 
Based on Table 4, it can be formulated as follows:

$$
\begin{gathered}
\mathrm{Y}=\alpha+\beta \_1 \mathrm{X} \_1+\beta \_2 \mathrm{X} \_2+\cdots+\beta \_4 \mathrm{X} \_4+\varepsilon \\
\mathrm{Y}=6,024-1,444 \mathrm{X} \_1+0,328 \mathrm{X} \_2-0,010 \mathrm{X} \_3+0,014 \mathrm{X} \_4
\end{gathered}
$$

Also, it can be known that variable X1 effect on $Y$. With regression coefficient $\beta \_1$ (X1) inversely proportional to $Y$, variable $X 2$ does not affect $Y, X 3$ affects $Y$. Regression coefficient $\beta \_3$ (X3) is inversely proportional to $Y, X 4$ variables affect $Y$ [21-23]. The regression coefficient $\beta \_4$ (X4) is positive, so it is inversely proportional to $\mathrm{Y}$.

It means that not all independent variables $(X)$ have a significant effect. Variable $X 2$ has no significant effect on time $(\mathrm{Y})$, then the new model formed as follow:

$$
Y=6,024-1,444 X \_1-0,010 X \_3+0,014 X \_4
$$

The result of foot-steps analysis is presented on Table 5.

Tabel 5. Anova of footstepswit time as dependent variable

\begin{tabular}{llccccc}
\hline & Model & Sum of Squares & df & Mean Square & F & Sig. \\
\hline 1 & Regression & 3161.569 & 4 & 790.392 & 342.780 & $.000^{\mathrm{a}}$ \\
& Residual & 2008.376 & 871 & 2.306 & & \\
& Total & 5169.945 & 875 & & & \\
\hline
\end{tabular}

a. Predictors: constanta, distance of baggage, number of ground service personnel, number of equipent, distance of the pasanger). Dependent Variable: time

Based on Table 5 above, it can be shown that the position of the test result point of significance

\begin{tabular}{|c|c|c|c|c|c|c|c|}
\hline \multirow{2}{*}{ Model } & \multicolumn{2}{|c|}{$\begin{array}{l}\text { Unstandardized } \\
\text { Coefficients }\end{array}$} & \multirow{2}{*}{$\begin{array}{c}\text { Standardized } \\
\text { Coefficients } \\
\text { Beta }\end{array}$} & \multirow{2}{*}{$\mathrm{t}$} & \multirow{2}{*}{ Sig. } & \multicolumn{2}{|c|}{ Collinearity Statistics } \\
\hline & B & Std. Error & & & & Tolerance & VIF \\
\hline 1 (Constant) & -.789 & 1.104 & & -.715 & .475 & & \\
\hline Personnel & -.022 & .109 & -.004 & -.199 & .843 & .973 & 1.028 \\
\hline Tools & .056 & .264 & .005 & .213 & .832 & .983 & 1.018 \\
\hline $\begin{array}{l}\text { Passenger's } \\
\text { distance }\end{array}$ & -.005 & .000 & -.282 & -9.589 & .000 & .516 & 1.938 \\
\hline $\begin{array}{l}\text { Baggage's } \\
\text { distances }\end{array}$ & .025 & .001 & .949 & 32.448 & .000 & .521 & 1.918 \\
\hline
\end{tabular}
and F-count is in the rejection of Ho, so Ho stating that no influence $\mathrm{X} 1, \mathrm{X} 2, \mathrm{X} 3, \mathrm{X} 4$ to $\mathrm{Y}$ is rejected $[18,22-24]$.

a. Dependent Variable: Time

it can be seen as follow:

$$
\begin{gathered}
\mathrm{Y}=\alpha+\beta \_1 \mathrm{X} \_1+\beta \_2 \mathrm{X} \_2+\cdots+\beta \_4 \mathrm{X} \_4+\varepsilon \\
\mathrm{Y}=-0,789-0,022 \mathrm{X} \_1+0,056 \mathrm{X} \_2-0,005 \mathrm{X} \_3+0,025 \mathrm{X} \_4
\end{gathered}
$$


It can be known that for the variable $\mathrm{X} 1$ does not affect $\mathrm{Y}$, the variable $\mathrm{X} 2$ has no effect on $\mathrm{Y}, \mathrm{X} 3$ variables affect time $(Y)$. With Regression Coefficient $\beta \_3(X 3)$ is inversely proportional to $Y, X 4$ variables affect $Y$. Regression coefficient $\beta \_4(X 4)$ is in line with Y. based on the explanation above, it can be seen that not all independent variables $(X)$ have a significant effect. Variable (X1) and (X2) has no significant effect on time $(\mathrm{Y})$ then it can be removed from the model, as can be formed as follow:

$$
Y=-0,789-0,005 X \_3+0,025 X \_4
$$

based the results of the regression analysis, it can be concluded that the variables that affect the delayed luggage is the distance of passenger and baggage, as on Table 7.

Tabel 7. The average og time different

\begin{tabular}{|c|c|c|c|c|c|}
\hline \multirow{2}{*}{\multicolumn{2}{|c|}{ Tipe }} & \multirow{2}{*}{$\mathrm{N}$} & \multicolumn{3}{|c|}{ Subset for alpha $=0.05$} \\
\hline & & & 1 & 2 & 3 \\
\hline \multirow[t]{4}{*}{ Duncan $^{\mathrm{a}, \mathrm{b}}$} & Bus & 86 & 2.9419 & & \\
\hline & Avio & 876 & & 3.6233 & \\
\hline & Jalan Kaki & 187 & & & 5.1604 \\
\hline & Sig. & & 1.000 & 1.000 & 1.000 \\
\hline \multicolumn{6}{|c|}{ Means for groups in homogeneous subsets are displayed. } \\
\hline \multicolumn{6}{|c|}{ a. Uses Harmonic Mean Sample Size $=165.590}$. \\
\hline
\end{tabular}

Based on the table 7 above, it shown that the smallest time-different averages between passengers and luggage occur when using Bus 25\%, Avio / Garbarata 31\% and Walk $44 \%$. It means the use of Bus more effectively to reduce the delays of passenger movement time.

\section{Discussion}

Based on data presented above, the equation of partial test can be calculated as presented on Table 8. It shows that the value of $\mathrm{X} 1, \mathrm{X} 2$, and $\mathrm{X} 3$ is inversely proportional to $\mathrm{Y}$, whereas the movement of the bus and walk or foot-steps, the value of $X_{1}$, and $X_{3}$ are inversely related to the value of $Y$, while the significant value of $X_{2}$ in the movement of the garbarata and buses does not affect the $Y$, it is different with values at the movement of the foot-steps where the independent variables $X_{1}$, and $X_{2}$ have no effect on the value of $Y$.

Tabel 8. Equation of partial test

\begin{tabular}{|c|c|c|c|c|c|c|}
\hline \multirow{2}{*}{ Access } & \multicolumn{6}{|c|}{ Value } \\
\hline & Equation & Constanta & $\beta X_{1}$ & $\beta X_{2}$ & $\beta X_{3}$ & $\beta X_{4}$ \\
\hline \multirow{2}{*}{ Garbarata } & $Y=$ & 6.820 & -0.968 & -0.376 & -0.005 & +0.015 \\
\hline & Sig. & 0,011 & 0,047 & 0,466 & 0.000 & 0.000 \\
\hline \multirow{2}{*}{ Bus } & $Y=$ & 6.024 & -1.444 & +0.328 & - 0.010 & +0.014 \\
\hline & Sig. & 0.000 & 0.000 & 0.250 & 0.000 & 0.000 \\
\hline \multirow{2}{*}{ Walking } & $Y=$ & - 0.789 & - 0.022 & +0.056 & - 0.005 & +0.025 \\
\hline & Sig. & 0.475 & 0.843 & 0.832 & 0.000 & 0.000 \\
\hline
\end{tabular}


The Anova mean square calculation results obtained that there is an influence on 3 passenger and baggage access to the average value of time difference, whereas Duncan test results can be known the average of time difference between the movement of passengers and luggage with access movement, those are : the smallest time difference when using buses, followed by garbarata and on foot, so it was concluded that using bus was more effective in reducing luggage reception at the arrival terminal of Sultan Hasanuddin International Airport Makassar [24,25].

\section{Conclusions}

Based on the 3 patterns of passenger movement (avoid bridge, bus, and walking), those have significant mean travel time difference between passengers and luggage, where the travel time of passenger movement is always smaller than the travel time of baggage movement. Variables that affect baggage delays are the position of parking stand (distance of movement of passengers and luggage to arrival terminal) and number of ground service personnel. To improve the quality of airport service, it is better to improve aircraft stand position, and increase the number of ground service personnel who have special expertise related to the field of responsibility in handling passengers and baggage, so can be minimize the errors in service and to accelerate the ground service worker. The ground service personnel from the starting airport is also expected to includes baggage which has been grouped / separated between the destination baggage and the transit baggage by using the net into the plane, so the luggage is neatly arranged and the destination airport service personnel no longer need to observe the baggage code when removing baggage from the aircraft.

\section{References}

1. Algifari. 1997. Analisis Regresi, Teori, Kasus dan Solusi, Edisi pertama. BPFE

2. Dickson, F. 2009 Evaluasi Pelayanan Bagasi Penumpang di Bandara Adi Sumarmo solo, Volume 21, Nomor 5.

3. Gujarati, D. 1999. Ekonometrika Dasar Alih Bahasa Sumarno Zain. Erlangga Jakarta.

4. Hastono, Y.S. 2008 Pelayanan Publik di Bandar Udara Polonia Medan, USU e-Respository

5. Hendarto 2001, Dasar-dasar Transportasi, lecture handout departemen Teknik Sipil ITB-Bandung

6. Horonjeff, R 1993 Planning and Design of Airport Book 4rd ISBN: 0-07-045345-4 by McGraw-Hill.Inc

7. IATA-Standart Ground Handling Agreament (SGHA)

8. Jinca, I.M.Y.Prof.Dr. 2011, Perencanaan Transportasi Program Pascasarjana UNHAS Makassar

9. Majid, S.A dan Warpani E.P.D Sekolah Tinggi Manajemen Transportasi (STMT) Trisakti 2009. Ground Handling-Manajemen pelayanan darat perusahaan penerbangan PT Rajagrafindo Persada, Jakarta

10. Mardoko, A. Desember 2008 Analisis Tingkat Kesesuaian dan Kesenjangan kualitas Pelayanan di Terminal Domestik Bandar Udara Juanda Surabaya, Warta Ardhia Vol.34 No.2

11. Morlok, E. K. 1991 Pengantar Teknik dan Perencanaan Transportasi. Penerbit. Erlangga,. Jakarta

12. Morlok, E. K 1984, Pengantar Teknik dan Perencanaan Transportasi ISBN: 32-00-017-6 Penerbit Erlangga

13. Mulyanto, R.F.H 1999 Ground Handling Tata Operasi Darat Gramedia Pustaka Utama Jakarta

14. Nasution, M.N 2008 Manajemen Transportasi edisi ke-3 Ghalia-Bogor Indonesia

15. Neufert, E. 1973 Data Arsitek jilid I Erlangga Jakarta

16. Rustian, K. 2003 Ekonomi Transportasi Karakteristik, Teori dan Kebijakan, Ghalia Indonesia Jakarta

17. Salim, A. 2008 4rd Manajemen Transportasi Grafindo Jakarta

18. Samsudin, R.S.IP. Juni 2008 Pelayanan bagasi di Bandar Udara Syamsudin Noor-Banjarmasin, Warta Aridhia Vol.34 No.1

19. Santoso, S. 2000, SPSS Statistik Parametik. PT Elex Media Komputindo Gramedia Jakarta.

20. Santoso, S. 2003. SPSS Mengolah Data Statistik Secara Profesional. PT. Elex Media Komputindo. Jakarta.

21. Sudjana. 1996 Universitas Gajah Mada, Yogyakarta Teknik Analisis Regresi Dan Korelasi Tarsito Bandung 
22. Susetyadi, A. Desember 2007 Pengkajian Pelaksanaan Kegiatan Pelayanan Bagasi Penumpang di Bandar Udara Juanda Surabaya, Jurnal Penelitian Perhubungan Udara Vol.33 No.2

23. Suwardjoko, W 1990. Merencanakan Sistem Perangkutan. Bandung Penerbit ITB.

24. Tamim, O.Z 2008 Perencanaan dan Pemodelan Transportasi. ITB-Bandung

25. Yuliawati, E. Pengkajian Perilaku Konsumen Terhadap Pemilihan Moda Warta Ardhia Vol.34 No.2, Desember 2008

This is an open-access article distributed under the terms of the Creative Commons Attribution 4.0 International License, which permits unrestricted use, distribution, and reproduction in any medium provided the original work is properly cited. 